\title{
REDESIGN (MENDESAIN KEMBALI) ORGANISASI MELALUI PEMANFAATAN SISTEM INFORMASI
}

\author{
Hari Mantik \\ hari.mantik@yahoo.com
}

\begin{abstract}
Abstrak
Perubahan teknologi memicu organisasi berpikir ulang untuk melakukan rekayasa ulang dalam mendesain organisasi nya. Tetapi apakah dengan membangun sistem baru akan mampu mengubah jalan perusahaan menjadi lebih baik, atau justru membuat organisasi menjadi semakin mundur? Para pemimpin organisasi juga perlu dengan baik menterjemahan apa perubahan itu. Apakah hanya sebatas mengubah pola struktur organisai, mengubah sistem, atau mengubah pola berpikir?

Redesign (mendesain kembali) organisasi melalui pemanfaatan sistem informasi merupakan tulisan yang lebih menekankan pada pilihan mengapa organisasi harus berubah, dan sejauh apa pentingnya perubahan tersebut berdampak pada organisasi.
\end{abstract}

\section{PENDAHULUAN}

Manajemen, teknologi, dan organisasi merupakan suatu kombinasi sinergi yang tidak dapat dipisahkan. Manajemen memerlukan suatu payung yang di sebut organisasi. Organisasi memerlukan suatu landasan dalam bentuk format terstruktur yang kita terjemahkan sebagai manajemen. Organisasi dan manajemen sangat tergantung pada infrastruktur dan teknologi sebagai alat bantu proses bisnis internal maupun eksternal agar berjalan secara efisien dan efektif. Ada beberapa cara dan alasan dalam mendesain ulang suatu organisasi melalui sistem informasi, yaitu dengan melakukan 'perencanaan manajemen perubahan dalam organisasi', melakukan 'BPR/business process engineering', 'melihat secara keseluruhan/overview pengembangan sistem', dan 'mencari pendekatan alternatif dalam pengembangan sistem'.

\section{Perencanaan manajemen perubahan dalam organisasi}

Sistem informasi lebih dari sekedar perangkat lunak dan perangkat keras. Sistem informasi merupakan perpaduan antara elemen-elemen teknis dan elemen sosial. Sistem informasi harus mempunyai kaidah-kaidah keahlian (skills), deskripsi pekerjaan (jobs), manajemen dan organisasi, dimana tidak akan mungkin terjadi transfer teknologi tanpa ada manusia (people) di belakangnya. Phillip Kottler menegaskan, dengan melihat pentingnya on-line marketing, secara struktur sangat perlu menambahkan posisi $\mathrm{CCO}$ (chief communication officer) dan CIO (chief information officer) dalam memperkuat organisasi yang terintegrasi dengan teknologi informasi. Pendapat tersebut semakin memperjelas peranan sistem informasi dalam suatu organisasi.

\section{Spektrum perubahan organisasi}

Teknologi informasi memberikan beberapa derajat/tingkatan dalam perubahan organisasi. Seperti yang digambarkan oleh Kenneth dan Jane Laudon, terdapat empat jenis tahapan dalam perubahan struktur organisasi (automation, rationalization, reegineering dan paradigm shift) masing-masing memberikan resiko dan hasil (return) yang signifikan bagi organisasi. 


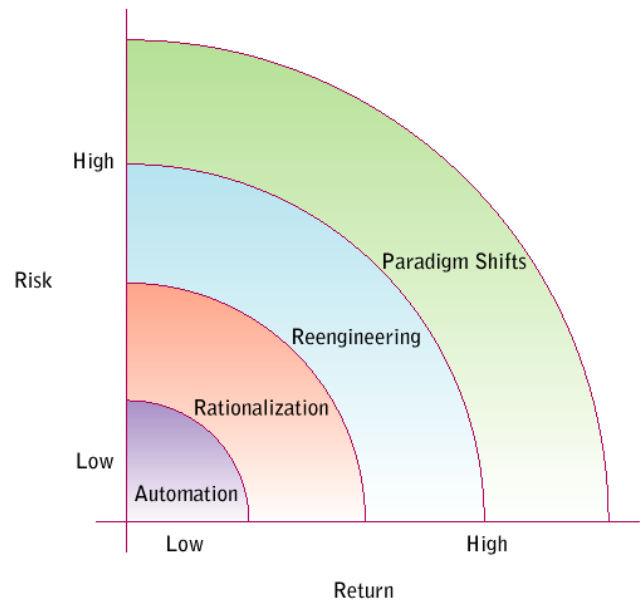

Gambar 1: Resiko dan hasil dalam perubahan organisasi (Laudon, managing informatioon system: managing digital firm)

Gambar 1 menjelaskan bahwa semakin rendah resiko, semakin rendah juga pengembalian keuntungan yang diperoleh oleh organisasi. Begitu pula sebaliknya, semakin tinggi resiko, semakin tinggi pengembalian yang akan di peroleh. Berikut tahapannya:

1. Pada tahap automation (to assist employee to more effective), fokus sistem informasi dalam organisasi terbatas pada penggunaan komputer sebagai sarana pembantu dalam mempercepat penyelesaikan pekerjaan. Artinya sistem informasi belum tercipta, komputer digunakan masih sebatas alat/sarana pedukung.

2. Pada tahap rationalization, sistem informasi mulai menunjukkan kegunaannya sebagai alat bantu dan bagian dari penciptaan standard operating procedures. Sistem informasi mulai menjadi bagian dari organisasi dalam menghilangkan kemacetan dan tidak efisienya proses produksi (bottle neck) dalam jalur informasi sehingga menciptakan production line yang lebih hemat biaya dan waktu.

3. Pada tahap business process reengineering, sistem informasi merupakan suatu alat untuk mengoptimalkan biaya, kualitas dan pelayanan melalui analisis dan perancangan manajemen sistem informasi. Tahap ini adalah era penggunaan metodologi sistem informasi, seperti SDLC (system development life cycle) sebagai dasar pengembangan sistem informasi. SDLC tentu saja bicara mengenai bagaimana mendesain kembali suatu proses bisnis melalui tahapan analisis, desain, uji, dan implementasi. Artinya, penggunaan IT/IS adalah bagaimana organisasi melakukan re-think/redesign/re-organized proses bisnis mereka agar kecepatan, jasa layanan dan kualitas bisnis semakin baik secara terus menerus.

4. Pada tahap paradign shift, terjadi pergeseran paradigma dalam berpikir (pergeseran pemikiran dari capital intensive menjadi brand intensive, capital based economy menuju knowledge based economy, capital society bergeser ke information society, serta pergeseran strategi longterm menjadi short-term). Pergeseran pemikiran ini menjadi suatu (r)evolusi yang paling sulit dan paling beresiko mengalami kegagalan karena sangat memerlukan suatu komunitas yang kita sebut sebagai orchestrated organization (kesiapan gabungan perusahaan secara sinergis mulai dari SDM, manajemen, produksi, pemasaran, keuangan dan divisi teknologi yang saling terintegrasi). Dalam fase ini, kita tidak berpikir ulang atau mendesain ulang (re-think/re-design) tentang proses bisnis, tetapi kita rethinking the 
nature of the business and the nature of the organization it self (mendesain kembali alam dari bisnis dan organisasi itu sendiri). Sebagai contoh: Perusahaan Nike Amerika atau Google. Mereka tidak lagi sibuk merombak bisnis proses dan metodologi mereka, tapi mereka berpikir lebih ke nation dan nature dari negara yang berbeda. Artinya, bisnis proses akan dengan sendirinya akan mengikuti setiap langkah strategi yang disesuaikan dengan kebutuhan dari negara yang berbeda.

\section{Overview/melihat secara keseluruhan dari pengembangan sistem}

Ditinjau dari segi ruang lingkup ataupun tujuan, sistem informasi merupakan hasil dari pengambilan keputusan dalam organisasi, dan di bangun sebagai solusi dari berbagai macam problema yang di hadapi organisasi. Aktivitas yang mengarah untuk menghasilkan solusi sistem informasi ini disebut sebagai 'pengembangan sistem'/system development yang secara terstruktur mempunyai tahapan:

1. Information strategic planning; memfokuskan pada objektif dan strategi dari manajemen dalam mencermati bagaimana pengaruh teknologi informasi dalam organisasi dapat digunakan untuk menciptakan kesempatan baru dan keunggulan kompetitif.

2. Business area analysis; fokus pada proses dan kebutuhan informasi (information requirements) yang di perlukan dalam organisasi, analisis masalah, kebutuhan data, dan bagaimana proses-proses serta datadata tersebut saling ter-relasi.

3. System design; fokus pada bagaimana sistem yang di hasilkan akan sesuai dengan kebutuhan informasi. Pada tahap ini pengunaan keter- libatan user menjadi inti dari pendesainan sistem.

4. Construction, merupakan tahap implementasi dari suatu pengembangan sistem. Tahap ini merupakan tahap dimana spesifikasi sistem di terjemahkan dalam suatu kode program (programming), tahap di lakukannya testing, dan perubahan dari sistem lama ke sistem baru (conversion).

\section{Pendekatan alternatif pengembangan sistem}

Sistem dalam organisasi mempunyai tingkat kebutuhan dan kesulitan yang berbeda-beda. Kenneth Laudon memberikan beberapa alternatif dalam meredesain sistem informasi dalam organisasi.

1. Traditional life cycle, merupakan metodelogi tradisional pengembangan sistem informasi secara bertahap/melakukan partisi berdasarkan kebutuhan yang paling penting atau mendesak (dilihat dari tingkat kompleksitas ataupun biaya) secara sekuensial/berurutan.

2. Prototyping, adalah proses pembangunan sistem secara eksperimental dan cepat yang bertujuan agar lebih mudah melakukan evaluasi terhadap end-user.

3. Application software package, merupakan suatu set aplikasi perangkat lunak yang secara komersial di jual bebas untuk berbagai kebutuhan organisasi seperti program pembayaran gaji karyawan (payroll), program akuntansi (general ledger), dan sebagainya. Akan tetapi dewasa ini banyak organisasi mempunyai kebutuhan dasar fungsional yang sama, akan tetapi dengan metode yang unik. Application software package memberikan kemudahan perubahan dan penerapan (customization) untuk 
aplikasi perangkat lunak sesuai dengan kebutuhan perusahaan.

4. End-user development; di sini secara informal user membuat beberapa program sederhana sebagai alat bantu pekerjaannya (misalnya mulai dengan pembuatan program sederhana dengan menggunakan aplikasi office, hingga sistem database dengan memakai access, sampai ke pembuatan program kecil dengan alat bantu pemrograman berbasis objek).

5. Outsourcing; merupakan strategi perusahaan untuk lebih fokus pada core competencies yang dimilikinya. Beberapa perusahaan yang merasa bahwa teknologi informasi dalam perusahaan merupakan sarana penunjang akan melakukan outsourcing/pemberian sebagian pekerjaan kepada pihak ke tiga yang lebih kompeten.

\section{Pengaruh sistem informasi terhadap organisasi}

Pengaruh sistem informasi terhadap organiasi dapat dilihat dari sudut pandang teori ekonomi dan teori perilaku (economic theory dan behavioral theory).

1. Dari sudut pandang teori ekonomi, sistem informasi sebagai faktor pengganti modal dan tenaga kerja (capital and labor). Sistem informasi membantu perusahaan dalam menurunkan biaya operasional secara eksternal dan internal.

2. Dari sudut pandang teori perilaku, sistem informasi lebih di lihat dari berbagai macam landasan ilmu seperti sosiologi, psikologi, dan politik. Pengaruhnya terhadap organisasi bahkan terlihat lebih penting di banding teori ekonomi yang terlalu memandang sistem informasi sebagai barang substitusi atas modal dan tenagakerja. Dari sudut perilaku ini sistem informasi dapat mempengaruhi perubahan struktur organisasi (change hierarchy), mengubah sistem distribusi informasi dalam manajemen (distributing system), mempermudah penilaian kinerja organisai (evaluate performance), dan mempermudah dalam melakukan perubahan dalam organisasi (political affect to change).

\section{Kesimpulan dan saran}

Mendesain kembali organisasi dengan memanfaatkan sistem informasi tidak hanya terkait pada sisi teknis 'bagaimana memulainya'. Apakah melalui pendekatan melihat secara keseluruhan sistem dengan tahapan analis hingga implementasi, atau melalui beberapa pendekatan alternatif seperti membuat prototyping dan melakukan strategi outsourcing untuk mempertahankan kompetensi inti. Tetapi yang penting diperhatikan juga adalah 'bagaimana melakukannya'. Hal yang tersulit dalam melakukan pendesainan ulang organisasi dengan bantuan sistem informasi adalah:

1. Bagaimana kita menterjemahkan paradigm shift? Mengubah pola pikir dari spektrum business process reingeneering menjadi spektrum rethinking of nature adalah pekerjaan rumah para pengambil keputusan saat ini

2. Bagaimana kita menata perubahan (managing change)? Menata perubahan terutama dalam organisasi berskala besar selalu terkait dengan menata keahlian dan menata SDM. Perubahan teknologi jika tidak diikuti dengan perubahan manusia (skills and behavior) akan berakibat strategi paradigm shift tidak akan 
berjalan sebagaimana yang diinginkan para pengambil keputusan. Seorang pemimpin harus jeli melihat fenomena perubahan ini sebagai suatu blue print atau cetak biru yang menterjemahkan seluruh strategi keberhasilan. Oleh karena itu, pemimpin harus tahu, perubahan adalah tantangan, bukan hambatan.

\section{REFERENSI}

Kottler, Phillip, Marketing Management, Prentice Hall, New Jersey, 2000

Laudon, Kenneth C. dan Laudon, Jane P., Management Information Systems, Managing the Digital Firm, Pearson Prentice Hall, New Jersey, 2004

Martin, James, Information Engineering, Book I: Introduction, Prentice Hall, New Jersey, 1989 